\title{
PENGARUH pH TERHADAP AKTIVITAS ENZIM KITINASE DARI ISOLAT ACTINOMYCETES DENGAN METODE SOMOGYI-NELSON
}

\author{
Welly Anggraeini \\ Program Studi Pendidikan Fisika IAIN Raden Intan Lampung \\ Diterima: 5 Agustus 2015 Disetujui: 10 Oktober 2015. Dipublikasikan: Oktober 2015
}

\begin{abstract}
The pH effect on chitinase enzyme activity of actinomycetes isolate by Somogyi-Nelson method has been done. Chitinase enzymes can be produced by chitinolytic microorganisms, actinomycetes. This actinomycetes is taken from Mangrove from Coastal Ringgung of Teluk Lampumg Waters, and has been isolated in previous research. The actinomycetes isolates used were ANL-12, ANL-9, ANLd-2b-3, and ANL-4, with chitinolytic activity of $1.9 \mathrm{~cm}, 2.0 \mathrm{~cm}, 2.3 \mathrm{~cm}$, and $5.0 \mathrm{~cm}$. The ANL-4 isolate, which has the largest chitinolytic activity, was selected for the next process, the solid state fermentation process (SSF) by the Somogy $i$-Nelson method. For this SSF process is done in one place. Chitinase enzyme activity was measured using microplate reader by the somogy i-Nelson method. enzyme activity is calculated by measuring the amount of glucose released in $\mu \mathrm{g} / \mathrm{ml}$ rough enzyme / hour $(\mathrm{U} / \mathrm{mL})$ by substrate reaction under certain conditions. From the research data showed that the purification enzyme had optimum activity at pH 7.0 with unit activity of 11,166 $\mathrm{U} / \mathrm{mL}$, while on chitin substrate without washing with $\mathrm{NaOH}$ yield optimum activity at $p \mathrm{H} 6$ with unit activity equal to $10,929 \mathrm{U} / \mathrm{ml}$.
\end{abstract}

\begin{abstract}
Abstrak: Telah dilakukan pengaruh $\mathrm{pH}$ terhadap aktivitas enzim kitinase dari isolat actinomycetes dengan metode Somogyi-Nelson. Enzim kitinase dapat diproduksi oleh mikroorganisme kitinolitik, yaitu actinomycetes. Actinomycetes ini diambil dari Lumpur Hutan Bakau asal Pantai Ringgung Perairan Teluk Lampumg, dan telah diisolasi pada penelitian sebelumnya. Isolat actinomycetes yang digunakan adalah ANL-12, ANL-9, ANLd-2b3, dan ANL-4, dengan memiliki aktivitas kitinolitik berturut-turut $1,9 \mathrm{~cm}, 2,0 \mathrm{~cm}, 2,3 \mathrm{~cm}$, dan 5,0 cm.Isolat ANL-4 yang memiliki aktivitas kitinolitik terbesar ini dipilih untuk proses selanjutnya, yaitu proses Solid State Fermentation (SSF) dengan metode Somogyi-Nelson. Untuk proses SSF ini dilakukan dalam satu tempat. Aktivitas enzim kitinase diukur menggunakan microplate reader dengan metode Somogyi-Nelson. Aktivitas enzim dihitung dengan mengukur jumlah glukosa yang dilepaskan dalam $\mu \mathrm{g} / \mathrm{ml}$ enzim kasar/jam $(\mathrm{U} / \mathrm{mL})$ oleh reaksi substrat dengan kondisi tertentu. Dari data penelitian menunjukkan bahwa enzim hasil pemurnian mempunyai aktivitas optimum pada $\mathrm{pH} 7,0$ dengan aktivitas unit sebesar $11,166 \mathrm{U} / \mathrm{mL}$, sedangkan pada substrat kitin tanpa dicuci dengan $\mathrm{NaOH}$ menghasilkan aktivitas optimum pada $\mathrm{pH} 6$ dengan aktivitas unit sebesar 10,929 $\mathrm{U} / \mathrm{mL}$.
\end{abstract}

Kata Kunci : actinomycetes, kitin, kitinase, solid state fermentation (SSF)

\section{PENDAHULUAN}

Udang di Indonesia pada umumnya diekspor dalam bentuk udang beku $(30 \%$ $75 \%$ ) yang telah dibuang bagian kepala, kulit, dan ekornya (Purwanti, 2014). Limbah kulit udang mengandung konstituen utama yang terdiri dari protein, kalsium karbonat, kitin, pigmen, abu, dan lain - lain.
Kitin, polimer berantai lurus tersusun atas residu $\mathrm{N}$-asetilglukosamin melalui ikatan $\mathrm{B}$ $(1,4)$ yang terdapat berlimpah di alam setelah selulosa (Ghose, 1987; Lehninger, 1982; D. Nelson \& Cox, 2000). Penyebaran kitin yang relatif luas menjadikan enzim pendegradasi kitin, kitin deasetilase, berpotensi diaplikasikan untuk menghidrolisis kitin menjadi kitosan (GA, 
T, \& Sandford, 1989; Lee, Joo, Cho, Ha, \& Lee, 2000; Nita, 2009). Adanya konfigurasi B- tersebut membuat molekul glukosa mudah untuk membentuk serabut kristal fibriler yang kuat (Winarno, 1995), sehingga untuk merusaknya diperlukan suatu enzim yang spesifik (Alexander, 1977). Enzim spesifik yang digunakan untuk menghidrolisis kitin adalah enzim kitinase (Pratiwi, Susanto, \& Yaninda Alpha Kusuma, 2015; Sri, 2004).

Enzim kitinase dapat diproduksi oleh mikroorganisme kitinolitik, salah satunya adalah actinomycetes (Remya \& Vijayakumar, 2008; Suwandi, 1989), karena actinomycetes ini mampu untuk mensintesis metabolit senyawa yang memiliki aktivitas biologis dan spora dari actinomycetes sangat esensial untuk biokonversi (Lin \& Tanaka, 2006; Xu, Li, \& Jiang, 1996).

\section{Actinomycetes}

merupakan mikroorganisme yang paling efisien dalam menggunakan substrat bagi kelangsungan hidupnya (Ambarwati1, S, Sembiring, \& Subagus, n.d.; Hamidah, Ambarwati, \& Peni, 2013; Sulistyani, 2013). Substrat kitin mudah dihidrolisis oleh actinomycetes menjadi karbohidrat yang lebih sederhana (Du Toit, Oliver, \& Van Biljon, 1984; Volk \& Wheeler, 1993), selanjutnya karbohidrat ini akan digunakan dalam memproduksi etanol dengan bantuan fermentasi (Holker, Hofer, \& Lenz, 2004; M.Al-Tai, Amira, \& Al, 1989; Samsuri et al., 2001).

Proses hidrolisis dan fermentasi ini dapat dilakukan dalam satu tempat, dimana proses ini disebut sebagai proses fermentasi keadaan padat atau disebut Solid State Fermentation (SSF) (Pandey, Ricardo, \& Larroche. C, 2008; Pandey, Soccoll, \& Mitchell, 2000). Proses SSF ini, pertama kali dikenalkan oleh (Takagi, Abe, Suzuki, Emert, \& Yata, 1977) yang berhasil mengkombinasikan enzim kitinase dan yeast S. cerevisiae untuk fermentasi gula menjadi etanol. Menurut (Mitchel, D., Krieger, \& Berovic, 2006; Moo-Young, 1983) fermentasi keadaan padat (solid state fermentation) merupakan proses fermentasi yang melibatkan zat padat dalam suatu fasa cair. Dalam penerapan bioteknologi alternatif, pemanfaatan SSF menggunakan actinomycetes pendegradasi kitin pada udang dapat digunakan sebagai bioenergi dan bioproduk yang bermanfaat dengan biaya produksi yang murah (Angenent, Karim, Al-Dahlan, Wrenn, \& DomiguezEspinosa, 2004; Das \& Singh, 2004; Rifaat, El-Said, Hassanein, \& Selim, 2007; Sukara, 2006).

Berdasarkan hasil penelitian dari (Takagi et al., 1977), maka dalam penelitian ini difokuskan pada pengaruh $\mathrm{pH}$ terhadap aktivitas enzim kitinase dari isolat actinomycetes dengan metode SomogyiNelson. Metode Somogyi-Nelson adalah metode untuk menentukan jumlah perubahan glukosa dengan reagen tembaga dan reagen arsenomolibdat (N. Nelson, 1994). Metode Somogyi-Nelson ini dipilih karena memiliki kemampuan mendeteksi kisaran relatif perubahan gula yang tinggi, sedikit interferensi dari enzim dan biaya yang relatif lebih murah. Untuk proses fermentasi ini dapat dilihat dari karakteristik berdasarkan $\mathrm{pH}$ dan aktivitas enzim kitinase (berdasarkan jumlah glukosa yang direduksi) actinomycetes pada saat inkubasi (Ohno et al., 1996). Aktivitas enzim kitinase dihitung dari jumlah glukosa 
yang dilepaskan dalam $\mu \mathrm{g} / \mathrm{mL}$ enzim kasar/ jam (U/mL) enzim oleh reaksi substrat dengan kondisi tertentu (Mathivanan, 1995). Tujuan penelitian ini adalah untuk mempelajari kondisi $\mathrm{pH}$ optimum dan aktivitas enzim kitinase selama proses reaksi enzim substrat dan mempelajari substrat kitinolitik yang digunakan dalam aktivitas enzim kitinase (Suryanto \& Yurnaliza, 2005).

\section{METODE PENELITIAN \\ Media ISP - 2}

Medium ISP-2 terdiri dari $4 \mathrm{~g}$ yeast ekstrak, 10 g malt ekstrak, $4 \mathrm{~g}$ dekstrosa, dan $20 \mathrm{~g}$ agar dilarutkan dalam $1 \mathrm{~L}$ air laut steril kemudian diautoklaf. Setelah media sedikit dingin, ditambahkan cycloheximide $(25 \mu \mathrm{g} / \mathrm{mL})$ dan nalidixic acid $(25 \mu \mathrm{g} / \mathrm{mL})$ (Magarvey, Keller, Bernan, Dworkin, \& Sherman, 2004).

\section{Larutan Mineral Garam}

Larutan ini terdiri dari $0,4 \%$ $\left(\mathrm{NH}_{4}\right)_{2} \mathrm{SO}_{4}, \quad 0,6 \% \mathrm{NaCl}, \quad 0,1 \% \quad \mathrm{~K}_{2} \mathrm{HPO}_{4}$, $0,01 \% \mathrm{MgSO}_{4}, 0,01 \% \mathrm{CaCl}$, dan0,5\% kitin. Larutan disterilkan pada autoklaf selama 15 menit pada suhu $121^{\circ} \mathrm{C}$.

\section{Larutan Pereaksi Lowry}

Campurkan $1 \mathrm{~mL}$ larutan $\mathrm{B}$ dan 1 $\mathrm{mL}$ larutan $\mathrm{C}$ dengan $98 \mathrm{~mL}$ larutan $\mathrm{A}$. Larutan A yaitu $2 \% \mathrm{Na}_{2} \mathrm{CO}_{3}$ dalam $\mathrm{NaOH}$ 0,1 N. Larutan B berupa $1 \% \mathrm{CuSO}_{4} .5 \mathrm{H}_{2} \mathrm{O}$ dalam akuades. Larutan $\mathrm{C}$ terdiri dari $2 \%$ KNa-tartarat dalam akuades. Larutan D adalah Folin - Ciocalteu $1 \mathrm{~N}$.

\section{Larutan Pereaksi Somogyi - Nelson}

Larutan A (copper reagent) $28 \mathrm{~g}$ $\mathrm{Na}_{2} \mathrm{HPO}_{4}$ dan $40 \mathrm{~g}$ garam Rochelle (K-Natartarat) dilarutkan dalam $700 \mathrm{~mL}$ air destilasi. Larutan dipanaskan dan diaduk hingga larut kemudian didinginkan pada suhu ruang. $100 \mathrm{~mL} \mathrm{NaOH} 1 \mathrm{~N}$ dan $80 \mathrm{~mL}$ $10 \%$ w/v $\mathrm{CuSO}_{4} .5 \mathrm{H}_{2} \mathrm{O}$ ditambahkan $180 \mathrm{~g}$ $\mathrm{Na}_{2} \mathrm{SO}_{4}$ anhidrat kemudian dilarutkan hingga volume akhir mencapai 1 L. Larutan didiamkan pada suhu ruang selama dua hari. Setelah dua hari larutan disaring dan ditaruh dalam botol coklat.

Reagen B (arsenomolybdate reagent) $50 \mathrm{~g}$ ammonium molybdate dilarutkan dalam $900 \mathrm{~mL}$ air destilasi, $42 \mathrm{~mL} \mathrm{H}_{2} \mathrm{SO}_{4}$ pekat ditambahkan dan diaduk. $6 \mathrm{~g}$ Natrium arsenat $\left(\mathrm{Na}_{2} \mathrm{HAsO}_{4} .7 \mathrm{H}_{2} \mathrm{O}\right)$ dilarutkan dalam $25 \mathrm{~mL}$ air destilasi. Larutan ammonium molibdat dan asam ditambahkan pada larutan natrium arsenat. Selanjutnya diinkubasi pada suhu $37^{\circ} \mathrm{C}$ selama 2 hari. Setelah dua hari larutan disaring dan ditaruh dalam botol coklat.

\section{Larutan Buffer Pospat pH 6,5}

Sebanyak 0,964 g NaH${ }_{2} \mathrm{PO}_{4} . \mathrm{H}_{2} \mathrm{O}$ dan $0.8078 \mathrm{~g} \mathrm{Na}_{2} \mathrm{HPO}_{4} .7 \mathrm{H}_{2} \mathrm{O}$ dilarutkan dalam $100 \mathrm{~mL}$ air kemudian dicek pH-nya. Ditambahkan $\mathrm{NaOH}$ atau $\mathrm{H}_{3} \mathrm{PO}_{4}$ bila dibutuhkan. Ini merupakan buffer pospat pH 6,5 $1 \mathrm{M}$.

\section{Pertumbuhan Actinomycetes}

Strain actinomycetes yang digunakan adalah ANL-4 yang telah berhasil diisolasi dari sedimen mangrove pantai, ciri-ciri strain ini memiliki miselium aerial berwarna putih keabuan dan miselium substratnya berwarna krem keabuan. Strain 
actinomycetes ditumbuhkan dalam media ISP-2. Selanjutnya $25 \quad \mu \mathrm{g} / \mathrm{mL}$ cycloheximide dan $25 \mu \mathrm{g} / \mathrm{mL}$ nalidixic ditambahkan untuk menghindari kontaminasi jamur dan bakteri (Amorso, Clowell, \& Hill, 1998).

\section{Persiapan Inokulum}

Spora kultur 7-9 hari dipisahkan dan taruh dalam tabung Erlenmayer $250 \mathrm{~mL}$ berisi $100 \mathrm{~mL}$ larutan mineral garam. Tabung diletakkan pada shaker dengan kecepatan $175 \mathrm{rpm}$ pada suhu $30^{\circ} \mathrm{C}$ selama 5 hari.

\section{Fermentasi Keadaan Padat (Solid State Fermentation)}

Substrat yang digunakan adalah kitin, sebelum digunakan kitin direbus dengan $0,5 \% \mathrm{NaOH}$ selama satu jam berdasarkan metode (Gray, Hendy, \& Dunn, 1978; Sulistianingsih, 2006). Selanjutnya kitin dibilas dengan aquades, lalu disaring dan dikeringkan. Sebanyak $10 \mathrm{~g}$ substrat kitin dimasukkan dalam Erlenmayer $250 \mathrm{~mL}$. Substrat kemudian dilembabkan dengan 5 $\mathrm{mL}$ larutan mineral garam yang terdiri dari $0,4 \% \quad\left(\mathrm{NH}_{4}\right)_{2} \quad \mathrm{SO}_{4}, \quad 0,6 \% \quad \mathrm{NaCl}, \quad 0,1 \%$ $\mathrm{KH}_{2} \mathrm{PO}_{4}, 0,01 \% \mathrm{MgSO}_{4}, 0,01 \% \mathrm{CaCl} . \mathrm{pH}$ larutan dikondisikan pada 7,0 dan media disterilisasi pada $1 \mathrm{~atm}$ selama 15 menit. Sebanyak $5 \mathrm{~mL}$ kultur awal diinokulasikan dalam media kitin dan diinkubasi pada $25^{\circ} \mathrm{C}$ dengan shaking $175 \mathrm{rpm}$ selama 5 hari.

\section{Substrat Collodial kitin}

Sebanyak $10 \mathrm{~g}$ substrat kitin dimasukkan dalam Erlenmayer $500 \mathrm{~mL}$. Substrat kemudian dilembabkan dengan 10
$\mathrm{mL}$ larutan $\mathrm{HCl}$, lalu di stirer selama 4 jam. Campuran tersebut ditambahkan dengan 50 $\mathrm{mL}$ larutan etanol 95\%, di stirer kembali selama 30 menit dan didinginkan pada suhu $20^{\circ} \mathrm{C}$. Selanjutnya campuran dicuci dengan $0,1 \mathrm{M}$ buffer sodium phosphate ( $\mathrm{pH}$ 7),dan di sentrifius selama 20 menit pada suhu $4^{\circ} \mathrm{C}$. Hasil endapan yang didapatkan didiamkan selama 24 jam (Gijzen, Kuflu, Qutob, \& Chernys, 2001; Mathivanan, 1995).

\section{Uji Aktivitas Ekstrak Kasar Enzim}

Sejumlah hasil dari fermentasi keadaan padat (solid state fermentation) dicampurkan dengan $10 \mathrm{~mL}$ air destilasi dengan membiarkan tabung pada rotary shaker selama 1 jam pada $200 \mathrm{rpm}$ (Sheehan \& Himmel, 1999). Campuran disaring menggunakan kain katun dan filtrat disentrifugasi pada 10.000 rpm selama 20 menit pada suhu $4^{\circ} \mathrm{C}$. Supernatan yang diperoleh merupakan ekstrak kasar enzim (Fukamizo, 2000). Kadar protein ditentukan menggunakan metode Lowry dengan menggunakan standar BSA.

\section{Assay Enzim}

Pengujian aktivitas kitinase dilakukan menggunakan substrat collodial kitin $1 \%$ dalam buffer pospat $\mathrm{pH}$ 6,5. Aktivitas enzim merupakan jumlah dari glukosa yang dilepaskan dalam $\mu \mathrm{g} / \mathrm{mL}$ enzim kasar/jam $(\mathrm{U} / \mathrm{mL})$ oleh reaksi substrat dengan kondisi tertentu (Mathivanan, 1995; Paturau, 1982; Rahayu, 1990). Jumlah gula pereduksi yang dilepaskan dalam uji aktivitas kitinase diukur dengan modifikasi metode Nelson dari metode Somogyi dalam (Andansari, Desty Rusdiana, \& Achmad, 2014; Widayantil, Ciawi, \& Wiwik Susanah, 2013). Total protein ditentukan dengan 
menggunakan metode (Lowry, Rosebrough, Farr, \& Randall, 1951).

\section{Penentuan pH Optimum}

Untuk menentukan $\mathrm{pH}$ optimum dilakukan uji aktivitas dengan menggunakan ekstrak kasar enzim kitinase pada variasi $\mathrm{pH} 6,0 ; 6,5 ; 7,0$ dan 7,5. Ditambahkan $25 \mu \mathrm{L}$ substrat enzim kitinase yang $\mathrm{pH}-$ nya telah diatur yaitu 6,$0 ; 6,5 ; 7,0$ dan 7,5 dalam well microplate.Sebanyak 25 $\mu \mathrm{L}$ ekstrak kasar enzim ditambahkan dalam setiap wellmicroplate. Campuran diinkubasi pada temperatur $45^{\circ} \mathrm{C}$ selama 30 menit dan didinginkan, kemudian diinkubasi kembali di atas penangas air pada temperatur $70^{\circ} \mathrm{C}$ selama 15 menit. Kadar gula pereduksi dihitung menggunakan metode SomogyiNelson.

\section{Metode Somogyi - Nelson}

Mikroassay untuk gula pereduksi merupakan modifikasi dari uji aktivitas Somogyi-Nelson dalam 96 well mikroplate. Substrat tanpa enzim digunakan sebagai kontrol. Sebanyak $25 \mu \mathrm{L}$ substrat dalam buffer pospat $\mathrm{pH}$ 6,5 dan $25 \mu \mathrm{L}$ sampel ditaruh dalam setiap well. Plat diinkubasi pada suhu $45^{\circ} \mathrm{C}$ selama 30 menit. Sebanyak $75 \mu \mathrm{L}$ copper reagent ditambahkan dalam setiap well. Untuk menghentikan hidrolisis plat diinkubasi pada suhu $80^{\circ} \mathrm{C}$ selama 10 menit. Sebanyak $20 \mu \mathrm{L}$ arsenomolybdate reagent ditambahkan dan well dihomogenkan. Serapan absorbansi diukur pada panjang gelombang $630 \mathrm{~nm}$. Kadar glukosa yang terbentuk ditentukan dengan menggunakan kurva standar glukosa konsentrasi 100 sampai $2000 \mu \mathrm{g} / \mathrm{mL}$.

\section{Total Protein}

Mikroassay untuk total protein merupakan modifikasi dari metode (Lowry et al., 1951). Dalam 96 well mikroplate, sebanyak $40 \mu \mathrm{L}$ sampel ditambahkan ke dalam setiap well. Kemudian ditambahkan $200 \mu \mathrm{L}$ reagen Lowry yang telah dimodifikasi (awalnya kompleks (II)protein akan terbentuk sebagaimana metode biuret), dihomogenkan selama 30 detik dan didiamkan pada suhu ruang selama 10 menit. Ditambahkan $20 \mu \mathrm{L}$ larutan $\mathrm{D}$, dihomogenkan selama 30 detik dan diinkubasi pada suhu ruang selama 30 menit. Serapan diukur pada panjang gelombang $630 \mathrm{~nm}$, konsentrasi protein ditentukan dengan menggunakan kurva standar Bovine Serum albumin (BSA).

\section{HASIL DAN PEMBAHASAN}

Strain actinomycetes ini ditumbuhkan dalam media ISP-2, isolat actinomycetes yang digunakan adalah ANL-4, isolat ini telah berhasil diisolasi dari sedimen mangrove pantai dengan ciri-ciri strain ini memiliki miselium aerial berwarna putih keabuan dan miselium substratnya berwarna krem keabuan dengan memiliki indeks kitinolitik sebesar $5 \mathrm{~cm}$ (Gambar 1), serta memiliki kemiripan dengan gambar mikroskopis dari streptomyces $s p$ yang telah berhasil diisolasi dari tanah oleh (Nikolova, Stefka, Vanya, \& Lyubomira, n.d.; Sutedjo \& Kartasapoetra, 1991), sehingga dapat dikatakan bahwa isolat ANL-4 termasuk ke dalam genus streptomyces (Gambar 2). 


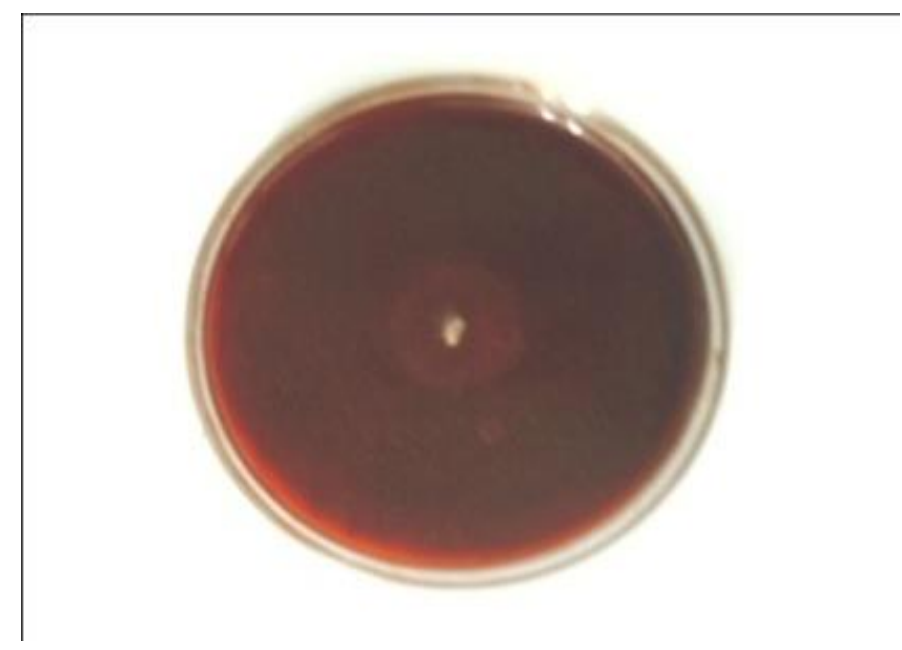

ANL-4

Gambar 1.Actinomycetes ANL-4 yang mempunyai kemampuan dalam mendegradasi kitin pada media mineral-salt agar plate dengan Kitin 1\% dengan pewarnaan Congo Red $1 \%$

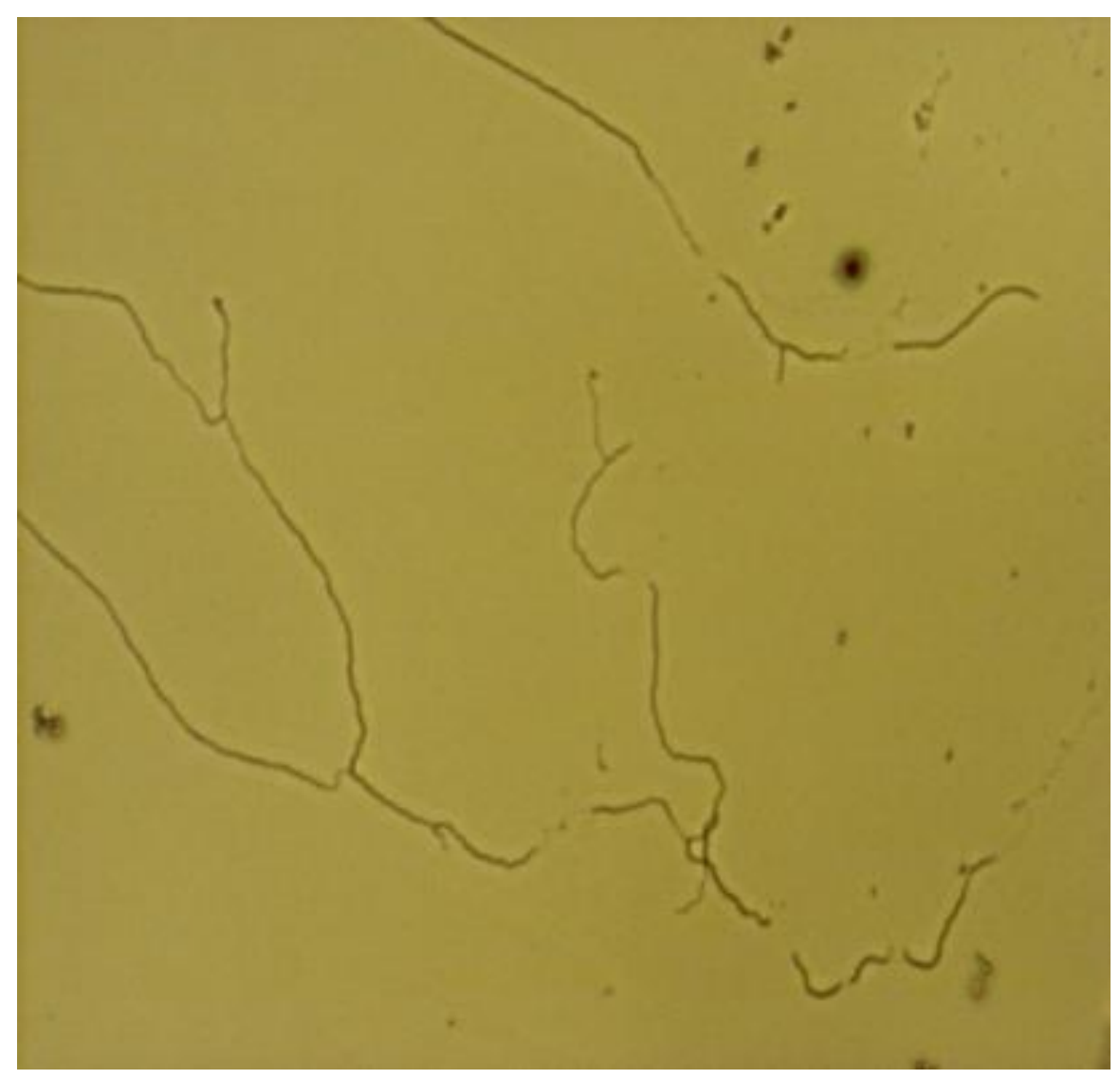

ANL-4 


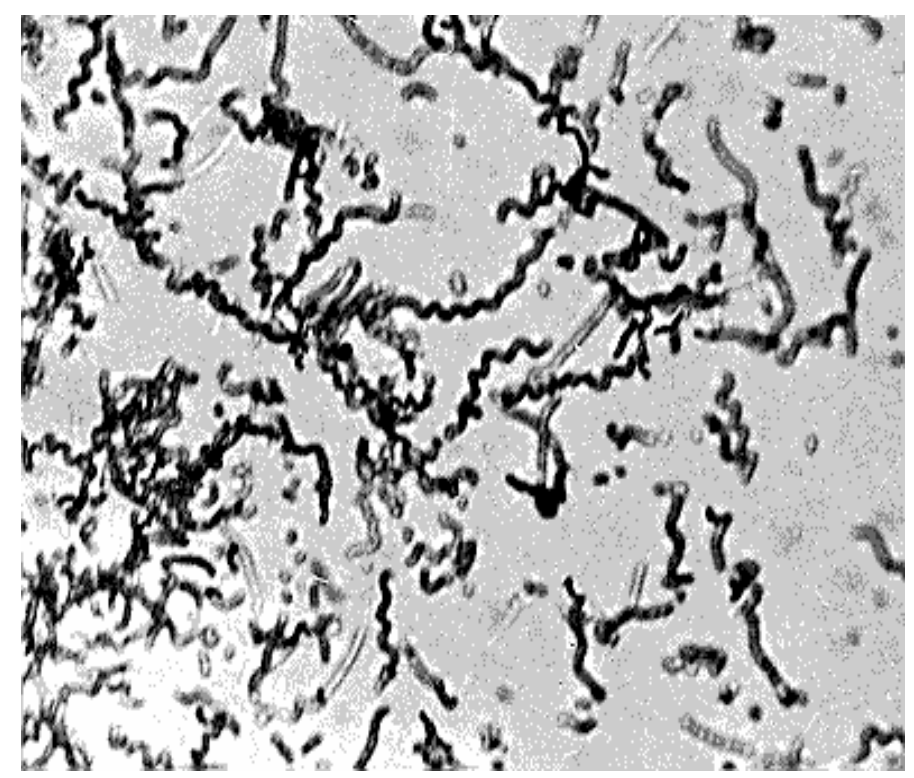

(Nikolova et al., n.d.)

Gambar 2. Isolat actinomycetes secara mikroskopik

Isolat actinomycetes yang akan diisolasi enzimnya, ditumbuhkan pada media mineralsalt sebanyak $100 \mathrm{~mL}$ kemudian media tersebut ditambahkan dengan $5 \mathrm{~mL}$ media mineralsalt yang didalamnya terdapat isolat actinomycetes (ANL-4), selanjutnya dikultivasi pada orbital shaker dengan kecepatan 175 rpm selama 5 hari. Hasil kultivasi yang didapat berwarna kuning kekeruhan, warna tersebut menunjukkan adanya pertumbuhan actinomycetes. Setiap isolat actinomycetes mempunyai warna yang berbeda-beda, jika dikultivasi dalam media mineralsalt. Setelah dikultivasi selama 5 hari, isolat actinomycetes (ANL-4) yang ada pada media mineralsalt dipisahkan antara biomasa dengan filtratnya.Kemudian filtrat yang diperoleh di sentrifius, dan hasil dari sentrifius tersebut merupakan ekstrak kasar enzim kitinase (Tsujibo, Okami, Tanno, \& Inamori, 1993).

Dalam proses fermentasi keadaan padat (SSF) ini menggunakan dua substrat yaitu kitin dicuci dengan $\mathrm{NaOH}$ dan kitin tanpa dicuci $\mathrm{NaOH}$. $\mathrm{NaOH}$ ini berperan sebagai pencuci untuk menghilangkan zat pengotor yang ada didalam kitin, dan dapat memutus gugus asetamida, sehingga pada penelitian ini tujuan menggunakan dua substrat tersebut adalah untuk membandingkan hasil antara kitin dicuci dengan $\mathrm{NaOH}$ dan kitin tanpa dicuci $\mathrm{NaOH}$.

Aktivitas enzim kitinase ditentukan berdasarkan jumlah dari glukosa yang dilepaskan dalam $\mu \mathrm{g} / \mathrm{mL}$ enzim kasar/jam $(\mathrm{U} / \mathrm{mL})$ enzim oleh reaksi substrat dengan kondisi tertentu (Mathivananet al., 1995).Aktivitas unit terbesar dimiliki oleh collodial kitin (kitin dicuci dengan $\mathrm{NaOH}$ ) dibandingkan dengan collodial kitin (kitin tanpa dicuci $\mathrm{NaOH}$ ) (Tabel 1).Substrat collodial kitin (kitin tanpa dicuci $\mathrm{NaOH}$ ) sedikit menunjukkan adanya aktivitas kitinolitik pada media mineralsalt.Hal ini dimungkinkan aktivitasnya telah hilang setelah masa inkubasi 7 hari.Kemampuan suatu mikroorganisme dalam 
mensekresikan enzim adalah berbedabeda.Tergantung pada jenis mikroba itu sendiri maupun media yang digunakan.

Tabel 1.Aktivitas unit enzim kitinase, kadar protein, dan aktivitas spesifik

\begin{tabular}{ccccc}
\hline No & Substrat & $\begin{array}{c}\text { Aktivitas Unit } \\
(\mathrm{U} / \mathrm{mL})\end{array}$ & $\begin{array}{c}\text { Kadar protein } \\
(\mathrm{mg} / \mathrm{mL})\end{array}$ & $\begin{array}{c}\text { Aktivitas } \\
\text { spesifik }(\mathrm{U} / \mathrm{mg})\end{array}$ \\
\hline 1 & $\begin{array}{c}\text { Collodial kitin (Kitin tanpa } \\
\text { dicuci } \mathrm{NaOH})\end{array}$ & $4,1399 \times 10^{-5}$ & 4,58708 & $9,04 \times 10^{-6}$ \\
\hline 2 & $\begin{array}{c}\text { Colloidal } \text { kitin }(\mathrm{Kitin} \text { dicuci } \\
\text { dengan } \mathrm{NaOH})\end{array}$ & $4,3157 \times 10^{-5}$ & 6,05631 & $7,12 \times 10^{-6}$
\end{tabular}

Ekstrak kasar enzim yang dihasilkan selanjutnya digunakan sebagai sampel utama untuk mengetahui pengaruh $\mathrm{pH}$ terhadap substrat selama reaksi. Penentuan $\mathrm{pH}$ optimum dilakukan dengan cara mereaksikan substrat dengan enzim dengan variasi $\mathrm{pH}$ yaitu 6,$0 ; 6,5 ; 7,0 ;$ dan 7,5 dimana substrat yang digunakan adalah kitin yang telah dicuci dengan menggunakan $\mathrm{NaOH}$ dan tanpa dicuci dengan $\mathrm{NaOH}$ (Suryanto \& Yurnaliza, 2005). Berikut ini hasil dari penentuan $\mathrm{pH}$ optimum enzim kitinase dengan substrat yang telah dicuci dengan $\mathrm{NaOH}$ dan tanpa dicuci dengan $\mathrm{NaOH}$ yang diperlihatkan pada Gambar 3.

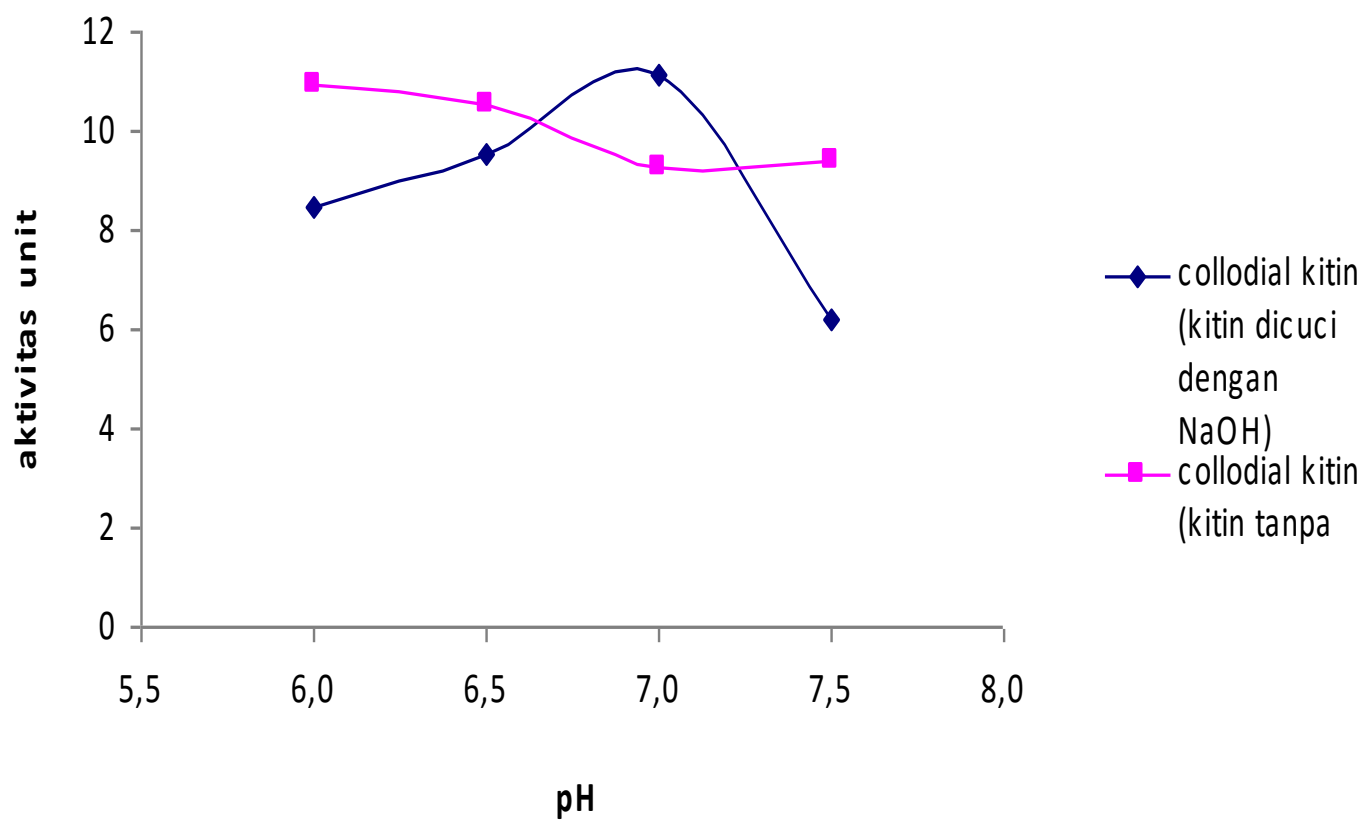

Gambar 3.Kurva $\mathrm{pH}$ optimum untuk enzim kitinase

Pada Gambar 3 dapat dilihat bahwa enzim kitinase dengan substrat yaitu kitin yang telah dicuci dengan $\mathrm{NaOH}$ menghasilkan aktivitas optimum pada $\mathrm{pH}$ 7,0 dengan aktivitas unit sebesar 11,166
$\mathrm{U} / \mathrm{mL}$, sedangkan pada substrat kitin tanpa dicuci dengan $\mathrm{NaOH}$ menghasilkan aktivitas optimum pada $\mathrm{pH} 6$ dengan aktivitas unit sebesar 10,929 U/mL.Berdasarkan uraian di atas, terjadi 
peningkatan $\mathrm{pH}$ optimum dari enzim kitinase dengan substrat yang telah dicuci dengan $\mathrm{NaOH}$ dibandingkan enzim kitinase dengan substrat tanpa dicuci dengan $\mathrm{NaOH}$. Hal ini diperkirakan karena $\mathrm{NaOH}$ dapat bersifat sebagai pencuci untuk menghilangkan zat pengotor dan dapat memutus gugus asetamida. Hal ini juga disebabkan adanya pengaruh terhadap struktur ion pada enzim sehingga perubahan $\mathrm{pH}$ lingkungan akan berpengaruh terhadap efektifitas bagian aktif enzim dalam membentuk ion komplek enzim substrat (Permatasari, Gulo, \& Lesmini, n.d.).

Aktivitas maksimum dicapai pada suatu $\mathrm{pH}$ tertentu, dan penyimpanganpenyimpangan dari $\mathrm{pH}$ tersebut menyebabkan berkurangnya aktivitas. Hal ini disebabkan adanya pertumbuhan mikroorganisme dipengaruhi oleh berbagai keadaan fisik dan kimiawi, karena enzimlah yang mengkatalisis reaksi-reaksi yang berhubungan dengan proses kehidupan (Zhang, Himmel, \& Mielenz, 2006). Maka keadaan-keadaan tersebut sebenarnya mempengaruhi enzim dan juga mempengaruhi pertumbuhan.

\section{SIMPULAN DAN SARAN}

Simpulannya adalah ANL-4 memiliki aktivitas kitinolitik pada media mineralsalt agar dengan kitin 1\% (w/v) dengan indeks kitinolitik sebesar $5 \mathrm{~cm}$. pH optimum yaitu $\mathrm{pH}$ 7,0 dengan aktivitas unit sebesar 11,166 U/mL (kitin dicuci dengan $\mathrm{NaOH}$ ) dan $\mathrm{pH}$ 6,0 dengan aktivitas unit sebesar 10,929 U/mL (kitin tanpa dicuci $\mathrm{NaOH})$. Penelitian selanjutnya disarankan adalah untuk mempelajari karakter spesifik dari isolat actinomycetes ANL-4 yang mempunyai aktivitas kitinolitik paling besar serta mempelajari karakteristik enzim kitinase terhadap substrat dengan menggunakan teknik analisis HPLC dan FTIR.

\section{DAFTAR PUSTAKA}

Alexander, M. (1977). Introduction to Soil Microbiology (2nd ed.). New York: John Wiley and Sons.

Ambarwati1, S, T. A., Sembiring, L., \& Subagus, W. (n.d.). Uji Aktivitas Antibakteri Isolat Actinomycetes Dari Rizosfer Padi (Oryza Sativa) Terhadap Salmonella Typhosa dan Staphylococcus Aureus. Seminar Nasional X Pendidikan Biologi FKIP UNS, 1, 1-6.

Amorso, R., Clowell, M., \& Hill, R. (1998). Mercury-resistant Actinomycetes From The Chesapeake Bay. FEMS Microbiol Lett, 162, 177184.

Andansari, S. E., Desty Rusdiana, S., \& Achmad, R. (2014). Konversi Rumput Laut Menjadi Monosakarida Secara Hidrotermal. Jurnal Teknik Pomits, 3(2), 126-129.

Angenent, L., Karim, K., Al-Dahlan, M., Wrenn, B., \& Domiguez-Espinosa, R. (2004). Production Of Bionergy and Biochemicals from Industrial and Agricultural Wastewater. Trends in Biotechnology, 22, 477-485.

Das, H., \& Singh, S. (2004). Useful Byproduct From Cellulosic Wasters Of Agriculture and Food Industry acritical Appraisal. Crit Rev Food Sci Nutr, 44, 77-89.

Du Toit, P., Oliver, S., \& Van Biljon, P. (1984). Sugar cane bagasse as a possible source of fermentable carbohydrates: Characteristics of bagasse with regard to monosaccharide, hemicellulose and amino acid composition. BioTechnology and Bioengineering, 26, 1071-1078. 
Fukamizo, T. (2000). Chitinolityc enzymes: catalysis, substrate binding, and their application. Curr Prot Peptide Sci, 1, 105-124.

GA, S.-B., T, A., \& Sandford, P. (1989). Chitin and Chitosan: Sources, Chemistry, Biochemistry, Physical Properties and Applications. Elsevier ApplSci, London, 561.

Ghose, T. (1987). Measurement of cellulase activities. Pure \& App!.Chem, 59(2), 257-268.

Gijzen, M., Kuflu, K., Qutob, D., \& Chernys, J. (2001). A class I chitinase from soybean seed coat. J Exp Bot, 52, 2283-2289.

Gray, P., Hendy, N., \& Dunn, W. (1978). Digestion By Cellulolytic Enzymes Of Alkali Pretreated Bagasse. J. Aust. Inst. Agric. Sci, 210-212.

Hamidah, Ambarwati, \& Peni, I. (2013). Isolasi dan identifikasi isolat actinomycetes dari rizosfer padi (Oryza sativa L.) Sebagai Penghasil Antifungi. Naskah Publikasi, 1-15.

Holker, U., Hofer, M., \& Lenz, J. (2004). Biotechnological advantages of laboratory-scale solid state fermentation with fungi. Applied Microbiology and Biotechnology, 64, 175-186.

Lee, J. S., Joo, D. S., Cho, S. Y., Ha, J. H., \& Lee, E. H. (2000). Purification and characterization of extracellular chitinase produced by marine bacterium, Bacillus sp. LJ-25. J.Microbiol. Biotechnol, 10, 307-311.

Lehninger. (1982). Dasar-dasar Biokimia. Jakarta: Erlangga.

Lin, Y., \& Tanaka, S. (2006). Ethanol fermentation from biomass resources: current state and prospects. Applied Microbiology and Biotechnology, 69(6), 627-642.

Lowry, O., Rosebrough, N., Farr, A., \&
Randall, R. (1951). Protein Measurement With The Folin Phenol Reagent. J. Biol. Chem, 193, 265275.

M.Al-Tai, Amira, \& Al, E. (1989). Cellulase Production from Actinomycetes isolated from Iraqi Soils: I Characterization of A Celluloytic Streptomyces SP. Strain AT7. Journal of Islamic Academy of Sciences, 2(2), 185-188.

Magarvey, N. ., Keller, J. ., Bernan, V., Dworkin, M., \& Sherman, D. . (2004). Isolation and Characterization of Novel Marine-Derived Actinomycete Taxa Rich in Bioactive Metabolitest. Applied and Environmental Microbiology, 70(12), 7520-7529.

Mathivanan, N. (1995). Studies on Extracellular Chitines and Secondary Metabolites Produced By Fusarium Chlamydosporum, an Antagonist to Puccinia Arachidis, the Rust Pathogen Of Groundnut. University of Madras Chennai.

Mitchel, D., N., Krieger, \& Berovic, M. (2006). Solid-State Fermentation Bioreactors. Springer-Verlag Berlin.

Moo-Young, M. . (1983). Principles Of Solid State Fermentation. Arnold Publishers.

Nelson, D., \& Cox, M. (2000). Lehninger: Principles of Biochemistry. Madison: University of Wisconsin.

Nelson, N. (1994). A Photometric Adaptation Of The Somogyi Method For The Determination Of Glucosa. $J$. Biol. Chem, 153, 375-380.

Nikolova, Stefka, A., Vanya, S., \& Lyubomira, Y. (n.d.). Taxonomic Study Of Streptomyces sp. Strain 341. Journal Of Culture Collections, 5, $10-15$.

Nita, K. (2009). Pemanfaatan Limbah Kulit Udang Sebagai Bahan Baku 
Pembuatan Membran Ultrafiltrasi. Inotek, 13(2), 113-120.

Ohno, T., Armand, S., Hata, T., Nikaidou, N., Henrissat, B., Mitsutomi, M., \& Watanabe, T. (1996). A modular family 19 chitinase found in the prokaryotic organism Streptomycesgriceus. $J$ Bacteriol, 178, 5065-5070.

Pandey, A., Ricardo, C., \& Larroche. C. (2008). Current Developments in Solid-state Fermentation. Asiatech Publishers, INC. New Delhi.

Pandey, A., Soccoll, C., \& Mitchell, D. (2000). New developments in solidstate fermentation: I -Bioprocesses and products. Process Biochemistry, 35, 1153-1169.

Paturau, J. (1982). Byproducts of the Cane Sugar Industry (2nd ed.). Amsterdam: Elsevier.

Permatasari, H. R., Gulo, F., \& Lesmini, B. (n.d.). Pengaruh Konsentrasi $\mathrm{H} 2 \mathrm{SO} 4$ Dan $\mathrm{NaOH}$ Terhadap Delignifikasi Serbuk Bambu (Gigantochloa Apus ). Program Studi Pendidikan Kimia FKIP Universitas Sriwijaya, 131140.

Pratiwi, R. S., Susanto, T. E., \& Yaninda Alpha Kusuma, W. (2015). Enzim Kitinase Dan Aplikasi Di Bidang Industri. Jurnal Pangan Dan Agroindustri, 3(3), 878-887.

Purwanti, A. (2014). Evaluasi Proses Pengolahan Limbah Kulit Udang Untuk Meningkatkan Mutu Kitosan Yang Dihasilkan. Jurnal Teknologi, 7(1), 83-90.

Rahayu, K. (1990). Enzim Mikroba. Yogyakarta: Universitas Gajah Mada.

Remya, M., \& Vijayakumar, R. (2008). Isolation and characterization of marine antagonistic actinomycetes from west coast of India. Medicine and Biology, 15(1), 13 - 19.
Rifaat, H. ., El-Said, O. ., Hassanein, S. ., \& Selim, M. S. M. (2007). Protease Activity of Some Mesophilic Streptomycetes Isolated from Egyptian Habitats. Journal Of Culture Collections, 5, 16-24.

Samsuri, M., Gozan, M., Mardias, R., Baiquni, M., Hermansyah, H., Wijanarko, A., \& Schwarz, W. (2001). The Cellulosome and Cellulose Degradation By Anaerobic Bacteria. Appl. Microbiol. Biotechnol, 56, 634-649.

Sheehan, J., \& Himmel, M. (1999). Enzymes, energy, and the environment: a strategic perspective on the U.S. Department of Energy's Research and Development Activities for Bioethanol. Biotechnol Prog, 15, 817-827.

Sri, R. (2004). Karakteristik biokimiawi enzim termostabil penghidrolisis kitin. Makalah Pengantar Falsafah Sains, (Pps 702), 1-9.

Sukara, E. (2006). Biotrends. Majalah Populer Bioteknologi, 1(2).

Sulistianingsih. (2006). Teknik Pengomposan Limbah Padat Industri Gula dan Aplikasinya pada Lahan Pertanaman Tebu di PT GMP. In Laporan $P U$. Unila. Bandar Lampung.

Sulistyani, N. (2013). Keragaman Isolat Actinomycetes Berdasarkan Analisis RFLP Terhadap Gen NRPS. Jurnal Ilmiah Kefarmasian, 3(1), 81-94.

Suryanto, D. E. ., \& Yurnaliza. (2005). Eksplorasi Bakteri Kitinolitik: Keragaman Genetik Gen Penyandi Kitinase pada Berbagai Jenis Bakteri dan Pemanfaatannya. USU.

Sutedjo, M., \& Kartasapoetra, G. (1991). Mikrobiologi Tanah. Jakarta: Ineka Cipta.

Suwandi, U. (1989). Mikroorganisme 
Penghasil Antibiotik. Jakarta: Pusat Penelitian dan Pengembangan PT. Kalbe Farma.

Takagi, M., Abe, S., Suzuki, G., Emert, G., \& Yata, N. (1977). A Method For Production Of Alcohol Direct From Cellulose Using Cellulase and Yeast. Procedings Of The Bioconversion.

Tsujibo, H., Okami, Y., Tanno, H., \& Inamori, Y. (1993). Cloning, sequence, and expression of a chitinase gene from a marine bacterium, Alteromonas sp. strain $\mathrm{O}$ 7. J. Bacteriol, 175, 176-181.

Volk, W. ., \& Wheeler, M. . (1993). Mikrobiologi Dasar, Penerjemah Markham Edisi Kelima. Jakarta: Erlangga.

Widayantil, N. P., Ciawi, Y., \& Wiwik Susanah, R. (2013). Pengaruh Konsentrasi Ammonium sulfat ((Nlfu)zSOa) Sebagai Sumber Nitogen Terhadap Produksi Bioetanol Berbahan Baku Glocilaria sp. Journal Kimia (Journal Of Hemistry), 7(1), 110.

Winarno, F. (1995). Enzim Pangan. Jakarta: Gramedia Pustaka Utama.

Xu, L., Li, Q., \& Jiang, C. (1996). Diversity Of Soil Actinomycetes in Yunan, China. Applied and Environmental Microbiology, 62(1), 244-248.

Zhang, Y., Himmel, M., \& Mielenz, J. (2006). Outlook for cellulase improvement : Screening and selection strategies Biotechnology Advances. Elsevier. Amsterdam. 